\title{
QUOTATIONS FROM SCRIPTURE AND THE COMPILATION OF HEBREWS IN AN ORAL WORLD
}

\author{
Gert J. Steyn
}

University of Pretoria

Pretoria

\section{ABSTRACT}

This study interacts with the work of Pieter Botha by presenting four scenarios from my own research on the use of Septuagint quotations by Philo of Alexandria and by the unknown author of Hebrews. The first scenario draws attention to the fusion of oral and written traditions from the Septuagint Pentateuch as perceived in Philo's Vita Mosis. The second scenario refers to Philo's Therapeutae which is used as an example of an ascetic Jewish group who studied and contemplated on the 'Scriptures'. The third scenario tables an example of a first century C.E. catenatemplate for catechetical studies in an oral world - as found in 4 Maccabees. The fourth scenario shifts the emphasis to my research on the Septuagint Vorlage of the explicit quotations in Hebrews. It attempts to indicate, on the one hand, how the compilation of this document is based on a well-planned and well-thought through list of Scriptural passages, detectable in an underlying thread of 'promises'. On the other hand, it hopes to illustrate the complexity of an integrated process that fused oral and written traditions. The study concludes that the author lives in both an oral and a written world and draws from both during the compilation of his document. Hebrews represents a document at an advanced stage in the history of first century early Christianity and fuses oral and written traditions. But this is not just a random design. It is a well-planned and well-thought through document.

Keywords: Hebrews, Philo of Alexandria, Vita Mosis, Therapeutae, 4 Maccabees. 


\section{INTRODUCTION AND PURPOSE}

I wish to congratulate Pieter J. J. Botha on the reworking and compilation of eleven of his selected articles into a monograph on Orality and Literacy in Early Christianity. Pieter is well-known for his research in this important area and it is a great honour and privilege to engage in the discussion from the angle of my own research on quotations from Scripture - specifically those in Ad Hebraeos. Ever since I got acquainted with the famous work of Birger Gerhardsson on 'Memory and Manuscript' ${ }^{1}$ have I become sensitive for the complex relationship between the areas of orality and literacy in ancient biblical times.

I will present four scenarios from my own research on the use of Septuagint quotations by Philo of Alexandria and by the unknown author of Hebrews to interact with the work of Botha. In order to do so, I will extensively quote sections from my own work. Firstly, I would like to draw attention to the fusion of oral and written traditions from the Septuagint Pentateuch as perceived in Philo's Vita Mosis. ${ }^{2}$ Secondly, the case of Philo's Therapeutae will be used as an example of an ascetic Jewish group who studied and contemplated on the 'Scriptures.' ${ }^{3}$ Thirdly, an example of a first century C.E. catena-template for catechetical studies in an oral world, as found in 4 Maccabees, will be tabled. ${ }^{4}$ Lastly, the emphasis will shift to Hebrews. In presenting the results of my research on the Septuagint Vorlage of the explicit quotations in Hebrews, I hope to indicate, on the one hand, how the compilation of this document is based on a wellplanned and well-thought through list of Scriptural passages, detectable in an underlying thread of "promises. ${ }^{5}$ On the other hand, I hope to illustrate - at least to some extent - the complexity of an integrated process that fused oral and written traditions. ${ }^{6}$ One aspect that I will not address, but that I will only briefly refer to, is the audience of $\mathrm{Ad}$ Hebraeos and its reception in an aural community.

1 B. Gerhardsson, Memory and Manuscript: Oral Tradition and Written Transmission in Rabbinic Judaism and Early Christianity (ASNU 22; Lund: Gleerup, 1961).

2 Cf. G. J. Steyn, "Reflections on the Reception of the LXX Pentateuch in Philo's De Vita Mosis", in W. Kraus \& S. Kreuzer, Die Septuaginta: Text, Wirkung, Rezeption (4. Internationale Fachtagung veranstaltet von Septuaginta Deutsch (LXX.D), Wuppertal 19.-22. Juli 2012). Edited by Wolfgang Kraus and Siegfried Kreuzer. WUNT I 325. Tübingen: Mohr Siebeck, 2014), 363-80.

3 Cf. G. J. Steyn, “"Perfecting Knowledge and Piety” (Philo, Contempl. 3,25). Similarities between Philo's Therapeutae and Lukan Early Christianity,' Neotestamentica 43.2 (2009), 178-202.

4 Cf. G. J. Steyn, A Quest for the Assumed LXX Vorlage of the Explicit Quotations in Hebrews (Göttingen: Vandenhoeck \& Ruprecht, 2011), 299.

5 Cf. G. J. Steyn, 'An Overview of the Extent and Diversity of Methods Utilised by the Author of Hebrews When Using the Old Testament,' Neotestamentica 42.2 (2008), 327-52.

6 G. J. Steyn, Quest for the Assumed LXX Vorlage, 403-408. 


\section{QUOTATIONS: FOLLOWING THE TRAILS OF TRADITION TRAJECTORIES}

The practice of quoting from the words of sages, important and prominent figures, as well as from authoritative documents, is probably as old as humanity itself. Words of wisdom, ethical maxims, religious and legal instructions, societal conventions, mathematical and scientific formulas, etcetara not only tap into the wealth of knowledge and experience from previous generations - often irrespective of what the extent of their subjectivity of the matters quoted might have been - but are also applied by later generations as persuasive rhetorical devices to justify particular interpretations and opinions. This practice also applies to the authors and writers of the New Testament documents who fostered their theological argumentation on their interpretation of their authoritative religious Scriptures - which happened to be the same corpus of literature that was created, used and interpreted since the times of ancient Israel. Kravitz, almost apologetically, once started his exposition on the history of Hebrew literature stating that

[a]ncient Israel's artistic creation was literature. She produced no sculpture, no paintings, no plays as her heritage to the world. She is not renowned for her science, her philosophy, her sports. We do not remember her as a political giant or an economic innovator. Rather, she taught us religion. And we find it in the lives and literature of the Jews. ${ }^{7}$

Israel's understanding of her earliest history and the establishment of her religious codes eventually became collated and documented in her Torah scroll; her folklore and history became compiled in the historical scrolls of Samuel-Kings; her collection of prophetic visions, oracles and speeches were documented in the prophetic scrolls of Isaiah and Jeremiah, as well as in the collection of the Minor Prophets scroll; her poetry, prayers, lamentations, wisdom sayings and songs were compiled in the Psalms scroll and the other 'scriptures.' This phase is studied by Biblical scholars in applying the methodology of Literary Criticism within investigations that follow mainly a historical critical approach. But behind every such collection and every document lies a history of oral creation, transmission and collation of traditions. This preceding phase in the development of literature applies the tools of Form criticism and Tradition criticism within historical critical investigations.

By the time that the New Testament writers wrote their accounts in the earliest beginnings of early Christianity, they were familiar, on the one hand, with the authoritative scrolls of Jewish religious 'Scripture' and would often present their quotations using the formula 'as it is written.' On the other hand, however, they were also familiar with oral traditions which ran parallel to, interconnected with, and often supplemented, the existing documented versions of their Scriptures. In fact, even the Scriptures themselves contained for them the 'living word of God' so that they would use the formula 'as he

7 N. Kravitz, 3,000 Years of Hebrew Literature from the Earliest Time through the 20th Century (Chicago: The Swallow Press, 1972), xiii. 
says' for both the oral and the written traditions from which they have drawn when quoting from their traditions.

\subsection{SCENARIO 1: FUSING ORAL AND WRITTEN TRADITIONS: PHILO OF ALEXANDRIA AS AN EXAMPLE}

Botha quite rightly remarked: 'Thinking within (or conditioned by) an oral context and thinking within a literate context have distinct characteristics. But an approach that stresses oppositions is not very helpful. ${ }^{8}$ The context in which the ancient authors functioned - including those writers of the New Testament documents - is one which is neither oral, nor written, but both an oral and a written environment.

Philo of Alexandria (ca. 25 B.C.E. - 40 C.E.) is an appropriate analogy and a typical example of a Hellenistic Jewish contemporary to the New Testament writers who engaged with his sources in a manner where he fuses oral and written traditions. I touched on this fusion of oral and written sources in a publication on Philo's Vita Mosis and deliberated as follows:

'Philo's modus operandi in writing his narrative on the Life of Moses was to utilize both the oral tradition from the elders in his society, as well as the written tradition from his Scriptures, whilst consistently expanding and commenting on the events.' He writes:

(I) ... shall proceed to narrate the events which befell him, having learnt them both from those sacredscriptures $(\mu \alpha \theta \square v \alpha \square \tau \square \kappa \square \kappa \beta i ́ \beta \lambda \omega v \tau \square v \square \varepsilon \rho \square v)$ which hehasleftas marvellousmemorials of his wisdom, and having also heard many things from the elders of the nation ( $\kappa \alpha \square \pi \alpha \rho \alpha \operatorname{\tau } \tau \omega \omega v$ $\square \pi \square \tau \mathrm{o} \square \square \theta v o v \varsigma \pi \rho \varepsilon \sigma \beta v \tau \varepsilon \dot{\rho}(\omega v)$, for I have continually connected together what I have heard with

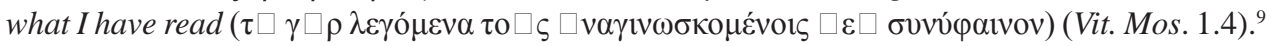

Oral tradition is thus used as an important source for Philo's narrative. He would often report that 'they say' $(\varphi \alpha \sigma r)^{10}$ and would frequently use similar clauses, indicating that he writes his own report of the events from, what he intends to be, the oral tradition. In addition to this, he also refers to 'sayings' or 'proverbs', using $\lambda$ ó $\gamma o{ }^{11} .{ }^{11} \mathrm{He}$ then presents the narrative through his own religious and philosophical hermeneutical filters.

8 P. J. J. Botha, Orality and Literacy in Early Christianity (Eugene: Cascade Books, 2012), 20.

9 The following work is used in this article for the Greek text of Philo: P. Borgen, K. Fuglseth \& R. Skarsten (eds), The Works of Philo: Greek Text With Morphology (Bellingham: Logos Bible Software, 2005). Throughout the article, the following work is used (with minute changes) for the English translation of Philo: C.D. Yonge (transl.), The Works of Philo: Complete and Unabridged (Peabody: Hendrickson, 1995).

10 This is a preferred term in Philo's vocabulary and it appears 241 times in the Corpus Philonicum. It is used 20 times in the Vita Mosis alone: 1.6, 9, 13, 17, 124, 126, 136, 165, 234, 268, 304, 330; 2.2, 38, 84, 98, 132, 168, 228, 235.

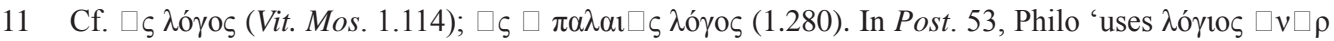

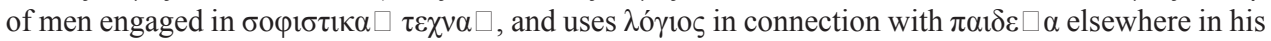
corpus'. In Mos. 1.2, he refers to 'Greek $\lambda$ o $\gamma \square$ ol, who abuse the power $\pi \alpha 1 \delta \varepsilon \square \alpha$ bestowed upon them' and in Mos. 1.23 'of Moses' education, which was at the hands of o $\square$ 入óyor of Egypt and others in specific areas of education...' (B. W. Winter, Philo and Paul amongst the Sophists. [Cambridge: University Press, 1997], 176). 
The role of the 'sacred Scriptures' being sacred and authoritative, on the one hand, and as additional sources to oral tradition, on the other hand, became clear from Philo's numerous references throughout the two-volume Vita Mosis.

i. He would often refer to the Scriptures as 'sacred' $\left(\square \varepsilon \rho{ }^{\prime} \varsigma\right)^{12}$ or as 'sayings' $\left(\lambda \operatorname{ó}_{1} \alpha\right)^{13}$ and would use it with the implied assumption that it is divinely inspired. He states for instance with regard to Moses: '....if he had not had these principles innate within him he would never have compiled those scriptures at the promptings of God' $(\varepsilon \square \mu \square \tau \mathrm{o} \square \square \tau \mathrm{o} \square \square \pi \varepsilon \varphi v ́ \kappa \varepsilon 1$,

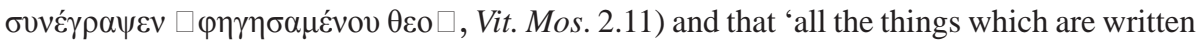
inthesacredbooksareoraclesdeliveredbyhim'( $\square \varsigma \pi \alpha ́ v \tau \square \varepsilon \square \sigma \square \chi \rho \eta \sigma \mu o$ í, $\square \sigma \alpha \square v \tau \alpha \square \varsigma \square \varepsilon \rho \alpha \square \varsigma$

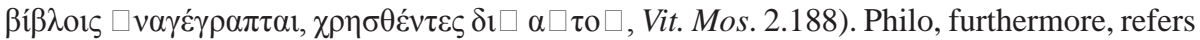

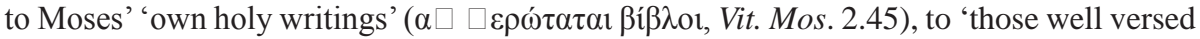

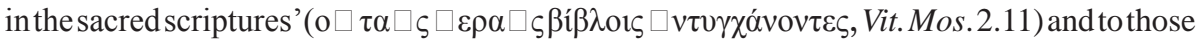
who 'having taken the sacred scriptures, lifted them up and their hands also to heaven'14

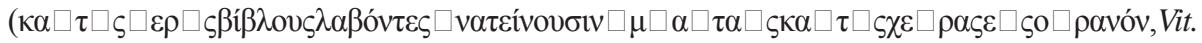
Mos. 2.36).

ii. References in this regard would often be in the plural, 'Scriptures' ( $\beta$ '́ $\beta \lambda \mathrm{ol}, \lambda$ ó $\gamma 1 \alpha)$, but sometimes also in the singular $(\gamma \rho \alpha \varphi \square, \lambda$ ó $\gamma \circ \varsigma)$.

iii. He would, furthermore, refer to the formulation and terminology used in the Scriptures during his exposition of the events he describes.

iv. There are hardly any explicit quotations to be found in the Vita Mosis and those that are posed in the Cohn-Wendland edition as explicit quotations are actually references or extended paraphrases. Philo himself wrote in this regard:

'And yet who is there who does not know that every language, and the Greek language above all others, is rich in a variety of words, and that it is possible to vary a sentence and to paraphrase the same idea, so as to set it forth in a great variety of manners, adapting many different forms of expression to it at different times' (Philo, Vit. Mos. 2.7 - my emphasis).

The genre of the retelling is that of a narrative which is being told from Philo's perspective. He would often add parentheses that state ' $I$ say'. Embedded into the main thread of the narrative runs a commentary in which he interprets the course events from his own religious and philosophical understanding - the latter which can be seen clearly in his constant return to the four basic elements of earth, air, water and fire. The commentary, furthermore, is a display of wisdom statements and proverbs. A further interesting feature of the retelling of the narrative is the presence of brief direct speeches that are often presented - not only in the mouth of Moses, but also by other prominent characters as the story unfolds. ${ }^{15}$

12 Cf. Vit. Mos. 1.4, 207; Vit. Mos. 2.11, 36; $\square \varepsilon \rho \alpha \square \beta \dot{\beta} \beta \lambda \mathrm{ol}$ (2.59); $\square \varepsilon \rho \square \varsigma \gamma \rho \alpha \varphi \square \varsigma$ (2.84); $\square \varepsilon \rho \alpha \square \varsigma \beta i ́ \beta \lambda o 1 \varsigma$ (2.95).

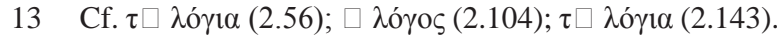

14 A similar description occurs also in Philo's discussion on the Therapeutae in Vit. Cont. 66. Cf. also Spec. Leg. 4.34; Flacc 121.

15 G. J. Steyn, 'Reflections', 364-66. 


\subsection{SCENARIO 2: STUDY AND CONTEMPLATION OF THE SCRIPTURES BY PHILO'S THERAPEUTAE}

One of the important aspects dealt with in the work of Botha, is the '... consideration of Greco-Roman writings as events, as situated "actions” where the issue is not a binary contrast between literacy and orality, not about people just decoding and encoding text, but rather as socially embedded and culturally mediated performances. ${ }^{16}$ The study, reflection and interpretation of authoritative texts by Judaeo-Christian religious communities in Hellenistic times - as 'socially embedded and culturally mediated performances' - is well attested in literature by these early Jewish and early Christian communities. One such case, elaborated upon by Philo of Alexandria in his book $D e$ Vita Contemplativa, is a peculiar Jewish group of ascetics, the Therapeutae, ${ }^{17}$ who lived on the outskirts of ancient Alexandria at Lake Mareotis. They meditated allegorically on the laws, prophetic oracles and psalms. ${ }^{18}$ Josephus wrote that they 'display an extraordinary interest in the ancient writings, particularly those for the welfare of the soul and body’ (J.W. 2.8.6 §136). I compared this group a few years ago with similar peculiarities as found in the Lukan writings and observed the following:

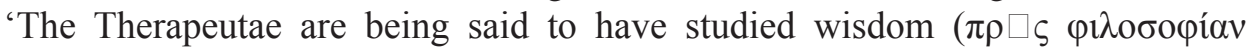
$\square \rho \mu \alpha \square \zeta$, Contempl. 2.16). In each of their houses "there is a consecrated room which is

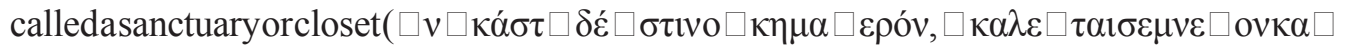

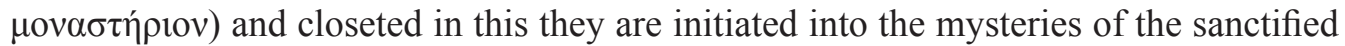

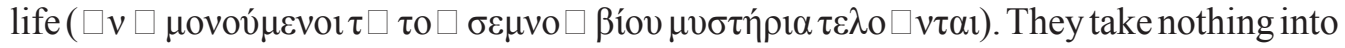
it, either drink or food or any other of the things necessary for the needs of the body, but laws and oracles delivered through the mouth of the prophets, and psalms and anything else which fosters and perfects knowledge and piety" (vó $\mu$ ov $\kappa \alpha \square \lambda$ ó $\gamma 1 \alpha \theta \varepsilon \sigma \pi 1 \sigma \theta \varepsilon \dot{v} \tau \alpha$

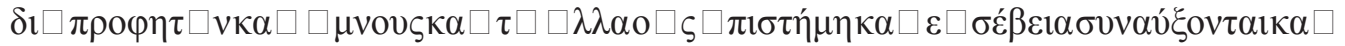
$\tau \varepsilon \lambda \varepsilon 10 \square v \tau \alpha$, Contempl. 3.25). They read the Holy Scriptures and seeked wisdom from their ancestral philosophy by taking it as an allegory (Contempl. 3.28). The writings of men of old they took as a kind of archetype and imitated the method (3.29). ${ }^{19}$ They followed the truly sacred instructions of the prophet Moses (Contempl. 8.64). During the banquet of the "chief feast of the fifty", the "President of the company" "discusses

16 P. J. J. Botha, Orality and Literacy, 87.

17 Cf. De vita contemplativa 2; De ebrietate 210; De decalogo 66; De specialibus legibus (lib.i-iv) 1; De praemiis et poenis \& De exsecrationibus 108; Legatio ad Gaium 97 and Quod omnis probus liber sit 75.

18 S. Mason, 'Jewish Theologies and Sects,' in Dictionary of New Testament Background (eds. C. A. Evans \& S. E. Porter; Downers Grove: Electronic Edition, 2000).

19 There is a strong case to be made that Luke used the technique of mimesis when he wrote his Gospel. A comparison between LXX 3 Kingdoms 17 and Luke 7 is a particular case in point; cf. G. J. Steyn, 'Luke's use of Mimesis? Re-opening the debate,' in The Scriptures in the Gospels (ed. C. M. Tuckett; Congress Volume of Papers delivered at the Colloquium Biblicum Lovaniense 51st Congress, August 1996; BETL 131; Leuven: Peeters Press, 1997), 551-8. 
some question arising in the Holy Scriptures or solves one that has been propounded by someone else' (Contempl. 10.76).

In Luke's Gospel, at the beginning of Jesus' ministry, soon after he returned from his temptations in the desert, he read from the Scroll of Isaiah in his local synagogue in Nazareth and explained to the listeners that what had been written there, applied to him and is fulfilled in him (Luke 4:16-30). Jesus again carefully explains the Scriptures to his disciples after his resurrection at the end of his ministry, indicating how these Scriptures applied to him, 'beginning with Moses and all the Prophets' (Luke 24:27). He 'opened their minds so they could understand the Scriptures' (Luke 24:45). Scripture is again quoted and interpreted in Acts in the speeches of Peter, Paul, Stephen and James thus being authoritative figures who are entrusted with the interpretation of Scripture. ${ }^{20}$ Philip takes a similar role as interpreter when he explains the passage from Isaiah to the Ethiopian eunuch (Acts 8:26-35). Also when the unknown author of Hebrews quotes from Scripture, he not only quotes from all three sections of the Scriptures (Torah, Prophets, Scriptures) but also places the quotations in the mouths of God, of the Son and of the Holy Spirit. ${ }^{21}$ However, for this unknown author of Hebrews, the Son is definitely and clearly greater than Moses.

Philo recorded the situation regarding the Therapeutae as follows: 'The exposition of the sacred Scriptures ( $\square \xi \eta \gamma \eta \dot{\sigma} \sigma \varepsilon 1 \varsigma \tau \square v \square \varepsilon \rho \square v \gamma \rho \alpha \mu \mu \alpha \dot{\tau} \omega v$ ) treats the inner meaning conveyed in allegory ( $\delta \mathrm{i} \square \square \pi \mathrm{ovor} \square v \square v \square \lambda \lambda \eta \gamma$ opía1s). For to these people the whole law book ${ }^{22}$ seems to resemble a living creature with the literal ordinances, for its body and for its soul the invisible mind ( $\square$ ópatov vo $\square v$ ) laid up in its wording. It is in this mind especially that the rational soul begins to contemplate the things akin to itself

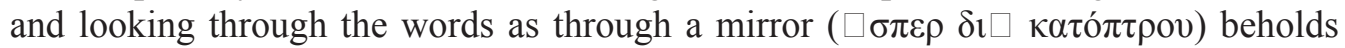
the marvellous beauties of the concepts, unfolds and removes the symbolic coverings ( $\left.\tau \square \mu \square v \sigma v ́ \mu \beta 0 \lambda \alpha \delta 1 \alpha \pi \tau v^{\prime} \xi \alpha \sigma \alpha \kappa \alpha \square \delta 1 \alpha \kappa \alpha \lambda v^{\prime} \psi \alpha \sigma \alpha\right)$ and brings forth the thoughts and sets them bare to the light of day for those who need but a little reminding to enable them to discern the inward and hidden through the outward and visible' ( $\square \kappa \mu \kappa \rho \square \varsigma \square \pi \circ \mu \nu \eta \dot{\sigma \varepsilon \omega \varsigma}$ $\tau \square \square \varphi \alpha v \square \delta 1 \square \tau \square v\left(\varphi \alpha v \varepsilon \rho \square v \theta \varepsilon \omega \rho \varepsilon \square v\right.$, Contempl. 10.78). ${ }^{23}$

\subsection{SCENARIO 3: AN EXAMPLE OF A CATENA-TEMPLATE FOR CATECHETICAL STUDIES FROM THE ORAL WORLD}

Whilst elaborating on the importance of orally transmitted teaching in Greco-Roman times, Botha - quite rightly in my opinion - concluded that '... it seems that a preference for orally transmitted teaching was widespread in Hellenistic times and in the Roman

20 G. J. Steyn, Septuagint Quotations in the Context of the Petrine and Pauline Speeches of the Acta Apostolorum (Kampen: Kok Pharos, 1995), 25.

21 Cf. G. J. Steyn, Quest for the Assumed LXX Vorlage, 24, 409.

22 Philo of Alexandria quotes 1161 times from Scripture of which only 41 quotations are not from the Pentateuch. See H. Burkhardt, Die Inspiration heiliger Schriften bei Philo von Alexandrien (Basel: Brunnen, 1988), 134.

23 G. J. Steyn, 'Perfecting Knowledge and Piety', 433-4. 
Empire' ${ }^{24}$ An interesting catechetical case emerges at the very end of the mid-firstcentury ${ }^{25}$ in 4 Maccabees (18:10-18) where one gets a glimpse of the 'teaching of the Law and the Prophets' by the then already deceased father to his seven sons ( $\square \varsigma \square \delta i \delta \alpha \sigma \kappa \varepsilon v$

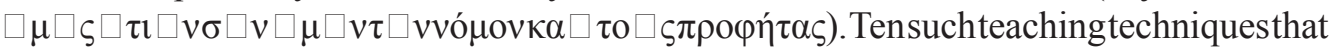
were utilised by their father are listed: ${ }^{26}$

i. 'Read about' ( $\square v \varepsilon \gamma i v \omega \sigma \kappa \varepsilon ́ v, v .11)$ - examples from Torah narratives.

ii. 'Told about' ( $\square \lambda \varepsilon \gamma \varepsilon v$, v. 12) - an example from the Torah.

iii. 'Taught about' ( $\square \delta i \delta \alpha \sigma \kappa \varepsilon ́ v$, v. 12) - an example from (possibly) the Prophets.

iv. 'Praised' ( $\square \delta o ́ \xi \alpha \zeta \varepsilon v, v .13)$ - an example from the Prophets.

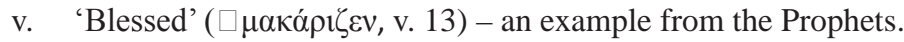

vi. 'Reminded of the Scripture' $(\square \pi \varepsilon \mu$ í $\mu v \square \sigma \kappa \varepsilon v$... $\gamma \rho \alpha \varphi \square v$, v. 14) - the Prophets.

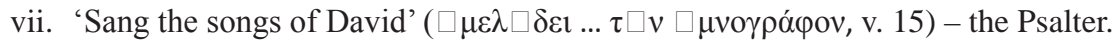

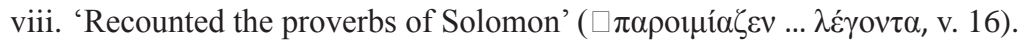

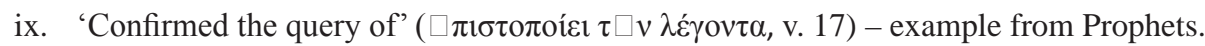

x. 'Teach the Song of Moses' ( $\square \delta \square v \ldots \square \delta i \delta \alpha \xi \varepsilon v$, v. 18) - from the Torah/Odes.

In Botha's opinion he considers the oral teaching tradition of 'a higher authenticityvalue than written texts.' He continues that '[t]he scribal culture of antiquity seems to exhibit a bias towards orality and little awareness of a dichotomization between the spoken and the written. The written was not set up over and against the spoken (as we moderns with our heavy literacy bias do), but the written was rather seen as an extension of speech. ${ }^{27}$

I am somewhat hesitant to prioritize, what Botha calls the 'higher authenticityvalue' of the oral tradition, as if it would have been of a higher priority and carrying more authority than the written tradition. Although it might be true that the oral tradition would carry more weight in certain specific contexts and times, I am rather inclined to keep both possibilities open, i.e. by acknowledging that also the written tradition might at times carry more weight than the oral tradition. Gerhardsson, for instance, defined the 'widest meaning' of the term 'Torah' 'as a collective designation for the whole of the authoritative, sacred tradition (doctrine); not merely that which is codified in sacred Scripture, but also that which is carried forward in sacral oral tradition ... - in fact everything which is understood as being God's sacred revelation to, and authoritative teaching of, his Covenant people. ${ }^{28} \mathrm{He}$ also stated elsewhere that:

24 P. J. J. Botha, Orality and Literacy, 37.

25 '4 Maccabees illumines the first-century environment of Judaism and Christianity and particularly some theological, social, and rhetorical features of New Testament texts, their settings, and their purpose' (D. A. DeSilva, Introducing the Apocrypha: Message, Context, and Significance [Grand Rapids: Baker Academic, 2002], 369-70).

26 Cf. G. J. Steyn, Quest for the Assumed LXX Vorlage, 299.

27 P. J. J. Botha, Orality and Literacy, 37.

28 B. Gerhardsson, Memory and Manuscript, 21. 
The distinction is therefore this: the one part of the Torah is in principle Scripture, Scripture which is read, whilst the other is oral tradition, tradition which is repeated. In the former case, the written text is official and plays a primary role; in the other, such notes as may exist are of private nature and play a subsidiary role.

This inter-changeability and equality of priority and authority of the oral and written traditions can also be observed in the way in which early Jewish (e.g. Philo, Josephus) and early Christian writers (e.g. Paul, Matthew, Luke) quote from their 'Scriptures' and introduce such quotations with the formula 'as it is written' - using such quotations from their religious literature as rhetorical devices to contribute to the persuasive nature of their theological arguments. I have pointed out in my research on Hebrews, however, that authors such as the unknown 'author of Hebrews prefer to introduce his explicit quotations with verbs of saying rather than with verbs of writing. ${ }^{29}$ Using forms of $\lambda \square \gamma \omega$, the author links his quotations to God, the Son or the Holy Spirit (Heb 3:7; 10:15). It was not an unknown practice to quote OT statements that were not made by God in their original contexts, as if they were indeed utterances of God.' 30

More refined is Botha's conclusion that 'we should move from a doctrine of Scripture to a more comprehensive theology of tradition' ${ }^{31}$ - a statement which I strongly endorse. This can be clearly observed in the author of Hebrews' utilization of 'promises' as traditions which were passed on both orally and in written form for generations and which this unknown author interprets at his time as having been fulfilled in the Jesusevent.

\subsection{SCENARIO 4: THE COMPILATION OF AD HEBRAEOS}

I am in full agreement with Botha that '[i]t is precisely the history of the book that can inform us about the techniques, practices and expectations of those who produced the texts studied in NT scholarship.' ${ }^{32}$

During the compilation and writing of a document, content and structure merge into a single package of stagnated language at a given point in time. Botha, quite rightly in my opinion, pointed out that '[s]tructure in most ancient writings is clearly mnemotechnically oriented, based on a logic of recollection, which is associative and determined by individual habit.' He continues, furthermore, that '[c]omposition was a memory based activity.' 33 This is in agreement with other scholars who have pointed out that 'writing began as an aide-mémoire, and that continued to be its primary function throughout the period when, no doubt, most transactions were completed orally and

29 Cf. Plato's Phaedrus (274b-77) where he warned that written words are dead and cannot answer back. True philosophy, however, is a live activity.

30 Cf., for instance, Matt 19:4 which cites Gen 2:24, and Acts 13:34 which cites Isa 55:2. (G. J. Steyn, Quest for the Assumed LXX Vorlage, 24).

31 P. J. J. Botha, Orality and Literacy, 38.

32 Ibid., 130-1.

33 Ibid., 107. 
traditions were memorized, ${ }^{34}$ and that 'the written text served as an aide memoire to a messenger and provided a permanent file copy for future reference. ${ }^{35}$

Although it is extremely difficult to reconstruct the process of compilation of most ancient documents, one can assume that - against this mnemotic background - authors would have collected pieces of the data that they used from both oral and written sources. This was confirmed in our opening scenario with Philo of Alexandria at the beginning of this paper. But how should one envisage the earliest beginnings of a collection of written notes? The answer is probably to be found in evidence from not only papyrus fragments, but also from ostraca. Metzger reminded us that '[o]straca are fragments of unglazed pottery vessels (which could be picked up from any rubbish heap) and were used in antiquity as we use scrap paper today. ${ }^{36}$ In Egypt, especially the finds of nonliterary ostraca provided evidence that these pieces of potcherds 'were the Egyptians' equivalent of memo-pads, jotters and scrap paper, and reflect every conceivable aspect of daily life. ${ }^{37}$

\subsubsection{THE EXTENT OF THE AUTHOR'S FAMILIARITY WITH PRE-HEBREWS QUOTATION-TRADITIONS}

The content of Hebrews displays a high density and frequency of quotations. It is not only an indicator of the important place that authoritative 'Scripture' had for the author and his familiarity with it, but also a window into the oral world of this unknown New Testament author. 'There are three clear groups of quotations that can be identified in Hebrews: (i) those that have parallels in the pre-Hebrews tradition, (ii) those that probably have parallels from the pre-Hebrews tradition relating to the same passage, but quoted from another section or expanding on an existing quotation by the author of Hebrews, and (iii) those that the author identified and applied himself and that are not to be found anywhere else in existing literature prior to Hebrews. The largest number of quotations belongs to the first two groups with occurrences in the Dead Sea Scrolls, Philo of Alexandria and the pre-Hebrews New Testament literature. Clear evidence was also found of the occurrence of some quotations in literature prior to Hebrews, that were thought to have been ascribed to the author of Hebrews himself in the past. ${ }^{38}$

As a well-educated person, it is clear that the author of Hebrews knew some quotations from the early Jewish and early Christian traditions. In some cases he merely reproduced the same quotation without any alterations - which probably points to

34 B. T. Arnold \& H. G. M. Williamson, Dictionary of the Old Testament: Historical Books (Downers Grove: InterVarsity Press, 2005), 1010.

35 J. M. Lindenberger, 'Letters,' in The Eerdmans Dictionary of Early Judaism (eds. J. J. Collins \& D. C. Harlow; Grand Rapids: Eerdmans, 2010), 883.

36 B. M. Metzger, Manuscripts of the Greek Bible: An Introduction to Greek Palaeography (Oxford: University Press, 1981) 54, n.154

37 K. A. Kitchen, 'Egyptian,' in New Bible Dictionary (eds. D. R. W. Wood et al; Downers Grove: InterVarsity Press, 1996), 863.

38 G. J. Steyn, A Quest for the Assumed LXX Vorlage, 378-9. 
second hand knowledge of such quotations via the oral (or written) traditions. In other cases he seemed to have been familiar with the broader context of some quotations and expanded on the known quotations or the passages from which they were taken. Yet, a third category of quotations could be classified as 'Sondergut-Hebraer' quotations and only occur by this unknown author. These are usually long and often editorially adapted.

\subsubsection{THE STRUCTURE OF QUOTATIONS IN HEBREWS AS A KEY TO ITS COMPILATION?}

Some years ago, I pointed to the underlying structure of quotations in Hebrews: If it is assumed that the quotations are forming the backbone of Hebrews and if the book is stripped from everything else so that only these quotations remain, then an interesting pattern unfolds. ${ }^{39}$ There are 34 quotations in Hebrews that can be identified, almost all of which are introduced with a clearly defined introductory formula. Some of these quotations appear more than once (Pss 2:7; 95:5-7; 110:4 and Jer 31:33-34) so that it actually leaves us with 26 different quoted texts - including the paraphrase of Gen 14:17-20 in Heb 7:1-3. The quoted texts seem to appear in combinations consisting of a pair of two quoted texts around a particular theme or motif ${ }^{40}$ - plus the combination of Ps 2:7 and Ps 110:4 (both repetitive quotations). Within the author's preference for ring compositions, the intention might have been to form an inclusio with the quotation from Ps 2: $7^{41}$ within the first section. Its combination with Ps 110:4 links then the first christological section (Jesus as King) with the second section (Jesus as High Priest). ${ }^{42}$

\begin{tabular}{|l|l|}
\hline Quotations & Theme in Hebrews \\
\hline Ps 2:7 + 2 Kgdms 7:14 / 1 Chr 17:13 & Relationship: Father - Son (1:5) \\
\hline Deut 32:43 + Ps 104:4 & Relationship: Son - angels $(1: 6-7)$ \\
\hline Ps 45:7 + Ps 102:26-28 & Eternal Kingship vs transitory heaven \& earth $(1: 8-12)$ \\
\hline Ps 110:1 + Ps 8:5-7 + commentary & Submission of all: to the Son (1:13), to humanity $(2: 6-7)$ \\
\hline
\end{tabular}

39 D. Moody Smith made a similar observation: 'Probably the key to Hebrews does not lie outside the book itself, but is to be found in an analysis of the author's use of the Scriptures in the context of his total work' ('The Use of the Old Testament in the New,' in The Use of the Old Testament in the New and Other Essays: Studies in Honor of William Franklin Stinespring [ed. J. M. Efird; Durham: Duke University Press, 1972] 3-65, here 59). Also G. H. Guthrie states that '[t]he author of Hebrews especially uses methods of interpretation and argumentation found in the Rabbis. His use of the Old Testament has been one of the most neglected topics in discussions on the structure of the book' (The Structure of Hebrews: A Text-Linguistic Analysis [NTS 73; Leiden: Brill, 1994], 45).

40 G. Van den Brink also observed this: '(het) valt ons op dat de schrijver meerdere keren twee of meer teksplaatsen aanhaalt om zijn uitspraak te bewijzen'. He reckons that the technique of using a combination of passages was probably developed on the basis of the principle of Deut 19:15 which points to the confirmation of an issue by two or three witnesses ('De schrift zegt of de Schrift fantaseert? Het gebruik van het Oude Testament in Hebreeën', in Verkenningen in de katholieke brieven en Hebreeën [eds. G. Van den Brink, et.al; Kampen: Kok Voorhoeve, 1993], 211-17, here 211).

41 Cf. G. J. Steyn, 'Psalm 2 in Hebrews,' Neotestamentica 37.2 (2003), 262-282.

42 The classic division consists of three sections: Heb 1:1 - 4:13; 4:14 - 10:31; 10:32 - 12:13 / 13:25. 


\begin{tabular}{|l|l|}
\hline Quotations & Theme in Hebrews \\
\hline $\begin{array}{l}\text { Ps 22(21):23 + Isa 8:17,18 + } \\
\text { commentary }\end{array}$ & Relationship: Jesus/believers (brothers, children (2:12-13) \\
\hline Ps 95:7-11 + commentary + Gen 2:2 & Rest: Canaan then, 'Today' now (3:1-4:13) \\
\hline Ps 2:7 + Ps 110(109):4 + commentary & Christ's appointment: King (5:5) and Priest (5:6) \\
\hline Gen 22:17 [Gen 14:17-20]43 + Ps 110:4 & Promise: Abraham and Melchizedek (6:13-7:28) \\
\hline Exod 25:40 + Jer 31:31-34 & Covenant: Tabernacle (8:5) vs New covenant (8:8-12) \\
\hline Exod 24:8 + Ps 40(39):7-9 & Sacrifices: Blood then (9:20), Body now (10:5-7) \\
\hline Deut 32:35,36 + [lsa 26+Hab 2:3-4] & Judgment: Punishment (10:30) vs Righteousness (10:37-8) \\
\hline Gen 21:12 + Prov 3:11 & Testing faith: Abraham (11:18), now children (12:5-6) \\
\hline [Deut 9:19 + Ps 18(17)] + Hag 2:6.21 & Shaking the earth then (12:21), future also heaven (12:26) \\
\hline Deut 31:6 / Gen 28:15 + Ps 118:6 & Festival tradition: God's presence, support (13:5-6) \\
\hline
\end{tabular}

Apart from the resemblance with the pesharim where combinations of texts were presented under a particular theme, also the issue of authority might have played a role here. As two witnesses testify to a case, the quoted texts in pairs would certainly provide authoritative support to each of the fourteen topics as addressed by the author. Those quoted texts from the first set are almost exclusively from the Psalms, with the exception of the following: 2 Kgdms 7:14; Deut 32:43; Isa 8:17-18 and Gen 2:2. However, except for the latter, these quotations also belong to a hymnic tradition so that all those from the first section seem to have been taken from a hymnic context, pointing to possible liturgical undertones.

The quoted texts from the latter set follow a pattern of combinations where the quotation pairs are alternated: Torah+Psalm; Torah+Prophet; Torah+Psalm; Torah+Prophet; Torah+Proverb; Torah+Prophet; Torah+Psalm. The book ends with a quotation from Ps 118 - a well-known liturgical text used during the Jewish feasts. It is not impossible, but highly unlikely that the author used an existing 'testimony book' for these quotations. More likely are the liturgical connections that were made by Simon Kistemaker ${ }^{44}$ and Markus Barth. ${ }^{45}$ Known existing liturgies from Jewish groups that

43 Gen 14:17-20 should rather be taken as a paraphrase than seen as an explicit quotation. See G. J. Steyn, 'The Vorlage of the Melchizedek Phrases in Heb 7:1-4,' Acta Patristica et Byzantina 13 (2002), 207-23.

44 'Believers in the first century had access to the Scriptures when they attended the worship services. There they memorized passages from the Old Testament, especially those from the Psalter, Proverbs, and Prophets' (S. J. Kistemaker, New Testament Commentary. Exposition of the Epistle to the Hebrews [Grand Rapids: Baker Book House, 1984], 373).

45 Cf. M. Barth who proposes the possibility of '...a liturgy, an order of worship, or a collection of hymns used before (or still in) the author's time' ('The Old Testament in Hebrews: An Essay in Biblical Hermeneutics,' in Current Issues in New Testament Interpretation. Essays in Honor of Otto A. Piper (eds. W. Klassen \& G. F. Snyder; London: SCM Press, 1962) 53-78, here 73). He believes that this might be standing behind the collection of texts presented in Hebrews 1-3. This is interesting but difficult to prove and remains speculative. 
have withdrawn from society, such as the Sabbath liturgy (Angel Liturgy, ${ }^{46}$ or Sabbath Sacrifices) with its thirteen Sabbaths, ${ }^{47}$ discovered amongst the Dead Sea Scrolls, comes here to mind. The similarities between these pairs of quoted texts with their connected themes, and the themes found in the Sabbath Sacrifices, might point in the direction of a similar group ${ }^{48}$ that could have shared a similar theology (such as their view on angels, the temple, Sabbath, covenant, etc.), as well as similar hermeneutics and techniques of re-interpretation of Scripture (such as pesharim, etc.)'. ${ }^{49}$

\subsubsection{AD HEBRAEOS: AN INTEGRATED PROCESS THAT FUSED ORAL AND WRITTEN TRADITIONS}

In my study on the book of Hebrews I applied a two-pronged approach in order to trace the assumed LXX Vorlage of the explicit quotations there. I used, on the one hand, a text-critical approach - the scholarly tool that assists researchers of ancient literature to follow the trajectory of the historical development of a written text. But I also applied, on the other hand, a tradition-historical approach - the scholarly tool that assists us to follow the trajectory of an oral tradition. My conclusions to the study were the following:

'Based on the above two angles of the investigation, i.e. the traditional historical and the text critical aspects of the investigation, the question can be asked: What might have been the underlying modus operandi for the selection of the utilised texts and the composition of the book?

\section{a. Liturgical traditions}

There are some clues that are pointing in the direction of a possible liturgical background or context:

- The high frequency of quotations from the Psalms, Odes and other hymnic sections. ${ }^{50}$

- The paralellistic, poetic, or hymnic tendencies in the presentation of the 'Jesus hymns', the conflated quotation of Isa 26:20 and Hab 2:3-4, as well as the format of the author's own re-quotation of Jer 31(38):33-34 and Ps 40(39):7-9.

- The use of Ps 95(94) during the Festival of Tabernacles (Sukkoth).

- The use of Gen 22 during the Day of Atonement (Yom Kippur).

46 For a possible implied correction of a skewed Christology, cf. G. J. Steyn, 'Addressing an Angelomorphic Christological Myth in Hebrews?’ HTS Theological Studies 59.4 (2003), 1107-28.

47 See also G. J. Steyn, 'The Eschatology of Hebews as Understood within a Cultic Setting,' in Eschatology of the New Testament and Some Related Documents (ed. J. G. van der Watt; WUNT 315; Tübingen: Mohr Siebeck, 2011), 429-50.

48 Such as the Therapeutae of whom Philo wrote in De vita contemplativa.

49 G. J. Steyn, 'Extent and Diversity of Methods', 329-331.

50 S. J. Kistemaker refers to the situation in Ephesians and Colossians in that they 'had become familiar with the Psalms in the local worship services in which the congregation sang "psalms, hymns and spiritual songs” (Eph 5:19; Col 3:16)' (Hebrews, 35). 
- The section that is quoted from Hag 2:6 which came from the vision on the $21^{\text {st }}$ of the seventh month (Tishri) - which is the day for the Festival of Tabernacles (Sukkoth).

- The cultic imagery, priesthood, sacrifices, sanctuary, and the allusion to the Day of the Atonement.

- The quotation from Ps 118(117) - the Hallel, with which the book ends, was a key passage during the great Jewish festivals.

- The influence of the Eucharistic formula and the reference to the baptism of the recipients.

- The climax with the 'arrival' of the recipients at 'Mount Zion and the heavenly Jerusalem'.

The importance of seven, which was key to the festivals: the catena in Hebrews 1 consists of seven quotations, Hebrews 3-4 emphasises the seventh day as the day of rest, and the two sets of seven pairs of quotations, as well as the pointers to the festivals of the seventh month, Tishri, might all support the background of Jewish festival motifs.

The backdrop of the Jewish liturgical tradition, particularly the Jewish festival traditions, might explain the parallels with the Dead Sea Scrolls and Philo, the high frequency of quotations from the Psalms and Odes, and the selection of passages from oracles or visions to the prophets. The Jewish festival calender, which represents the cultic rituals of early Judaism, might have provided our author with the basic template for his work. These Jewish traditions, in combination with the christological and eschatological hermeneutics of early Christianity, contributed to the basic layout of this work. The trend of constant alteration between known texts from the Jewish tradition and key texts from early Christianity plus the author's own addition of texts, fits this understanding. One might probably even go so far as to assume here a series of early Christian midrashim on the theology (and some texts) of the Jewish festivals. A similar methodology was observed in 4QMidrEschat and the pesharim of the Dead Sea Scrolls.

It seems probable that the author wrote in Alexandria - maybe as a convert from a community similar to that of Qumran or the Therapeutae. ${ }^{51}$ He most probably had access to an early version of the LXX - at least for the Torah, which shows resemblances with that used by Philo of Alexandria.

He was familiar with the Scriptural reference tradition of early Judaism and that of early Christianity - with an $85 \%$ overlap between the quotations used by himself and those in the Dead Sea Scrolls, Philo and the New Testament. The common ground for the origin of the quotations might thus probably be found in a liturgical tradition, based mainly on some of the Jewish festivals.

51 An interesting resemblance is found, apart from similarities in theology and early Jewish-Christian hermeneutics, in the use of the term $\theta \varepsilon \rho \square \pi \omega v$ for Moses (Heb 3:5) - which is a hapax legomenon - in the allusion to Num 12:7. 
Furthermore, there are some striking similarities between the remnant manuscript fragments of the Songs of Sabbath Sacrifice (4QShirShabb), also known as the Angelic Liturgy, from Qumran Cave 4 (4Q400-407), and an underlying procession in the sequence of quoted texts as presented in Hebrews. Does one have in Hebrews perhaps an implied early Christian reaction against a group that was involved in some sort of 'Angel Liturgy' or 'Heavenly Passover Ritual'? ${ }^{52}$ It is most likely that the author addresses a skewed Christology which might have seen Jesus as just another angel. This 'angelomorphic myth' is addressed particularly in the catena of quotations in Hebrews 1.

\section{b. A list of promises?}

It is certainly striking that $\square \pi \alpha \gamma \gamma \varepsilon \lambda \square \alpha$ is used several times in the context of the explicit quotations. The word is found eighteen times in Hebrews and its occurrences are indicated in brackets in the left column of the table below. This is very frequent in comparison with the LXX where the term is found only 21 times in the whole collection (only four times in the canonical books, and seventeen times in the deuterocanonical books). ${ }^{53}$ To this, one might add the occurrences of the related terms, $\square \mu v \square \omega$ (Heb 3:11,

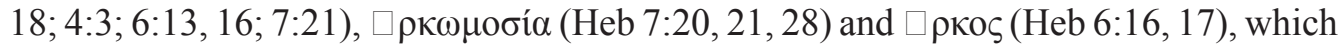
the author utilise in connection with God who made an oath by himself.

Some of these occurrences are found within the quotations themselves and are further elaborated upon by the author. These promises are presented and interpreted in the sense of 'a near and an ultimate fulfillment. ${ }^{54}$

\begin{tabular}{|l|l|l|}
\hline Promise & OT Passages & Hebrews \\
\hline Davidic: Royal messiah & $\begin{array}{l}\text { Ps 2:7; 2 Kgdms 7:14 } \\
\text { Deut 32 / Ode 2:43; Ps 104(103):4 } \\
\text { Ps 45(44):7-8; Ps 102(101):26-28 } \\
\text { Ps 110(109):1; Ps 8:5-7 } \\
\text { Ps 22(21):23; Isa 8:17, 18 }\end{array}$ & $1: 1-2: 18$ \\
\hline $\begin{array}{l}\text { Mosaic promise: Land / rest } \\
\text { (Heb 4:1) }\end{array}$ & $\begin{array}{l}\text { Ps 95:7-11; Gen 2:2 3:1-4:13 Ps 95:7-11; Gen } \\
\text { 2:2 }\end{array}$ & $3: 1-4: 13$ \\
\hline $\begin{array}{l}\text { Abrahamic promise (Heb 6:12, } \\
\text { 13, 15, 17; 7:6) }\end{array}$ & $\begin{array}{l}\text { Ps 2:7; Ps 110(109):4 } \\
\text { Gen 22:17 } \\
\text { Gen 14:17-20; Ps 110(109):4 }\end{array}$ & 4:14-7:28 \\
\hline $\begin{array}{l}\text { Jeremiah: Covenant renewal / } \\
\text { Eternal inheritance (Heb 8:6; } \\
\text { 9:15) }\end{array}$ & $\begin{array}{l}\text { Ex 25:40; Jer 31(38):31-34 } \\
\text { Ex 24:8; Ps 40(39):7-9 }\end{array}$ & \\
\hline $\begin{array}{l}\text { Habakkuk: 'Parousia' - righteous } \\
\text { shall live (Heb 10:23, 36) }\end{array}$ & Deut 32:35, 36; Hab 2:3,4 & 8:1-10:18 \\
\hline
\end{tabular}

52 See G. J. Steyn, ‘Angelomorphic Christological Myth,’ 1107-28; G. J. Steyn, ‘Eschatology,’ 448.

53 Cf. Est 4:7; Ps 55:9; Prov 13:12; Amos 9:6; Wis 2:13; Sir 20:23; 1 Macc 10:15; 11:28; 2 Macc 2:18; 4:8, 27, 45; 1 Esd 1:7; 3 Macc 1:4; 2:10; 4 Macc 12:9; Ode 12:6; Ps. Sol. 7:10; 12:6; 17:5.

54 R. D. Phillips, Hebrews, 30. 


\begin{tabular}{|l|l|l|}
\hline $\begin{array}{l}\text { Tests of faith in the promises unto } \\
\text { death } \\
(\text { Heb 11:9, 11,13,17,33,39) }\end{array}$ & Gen 21:12; Prov 3:11 & $11: 1-12: 11(?)$ \\
\hline $\begin{array}{l}\text { Haggai: Apocalyptic promise } \\
(\text { Heb 12:26) }\end{array}$ & Deut 9:19; Hag 2:6,21 & $12: 12-29$ \\
\hline
\end{tabular}

How should this be interpreted? Does this imply some kind of existing 'list of promises' (testimonia?) that might have been known amongst some early Christian circles, or is this our author's own creation? It is interesting to note the underlying promises to David, ${ }^{55}$ Moses, Abraham, Jeremiah, Isaiah, Habakkuk and Haggai. This phenomenon plus the occurrence of the $\lambda \square \gamma \varepsilon \mathrm{c}$ introductory formulae present us with a well planned compilation of prophetic 'logia' that seemingly underlies the presentation of the explicit quotations.

\section{c. $\quad$ Early Christian 'midrashim'}

It was pointed out before that a number of the explicit quotations were presented with an exposition, or commentary, by the author. These are the author's own compositions which he based on key words and components from the passages that he quoted. In a number of instances the New Testament context of these commentaries displays an awareness of the immediate Old Testament context of the passages from which the quotations were taken. ${ }^{56}$ The commentaries, or midrashim, relate particularly to the second quotation in each given pair of presented quotations, starting after the catena of Hebrews 1 and are usually attached to the longer of the two quotations. ${ }^{57}$ This trend was observed particularly with the quotations from Ps 8:5-7; [Isa 8:17-18?] Ps 95(94):7-11; Ps 110(109):4; Jer 31(38):31-34; Ps 40(39):7-9; Hab 2:3b-4; Prov 3:11-12; Hag 2:6; [Ps 118(117):6?]. ${ }^{58}$ It certainly presents us with the author's hermeneutic and his own particular exegetical method. The similarities with the pesharim of the Dead Sea Scrolls, the utilisation of the Jewish exegetical method of gezerah shewah, the ring compositional structure and poetic, or hymnic, presentation in many of these midrashim, not only reveal the author's Schriftverwendung, but also the author's theology. A particular inclination towards a christological and an eschatological hermeneutic became evident during this quest. The midrashartige nature of the compilation of promises certainly shows some similarities with what one encounters in the Dead Sea Scrolls in 4QMidrEschat.

It is no easy task to differentiate here between 'midrashim' or 'pesharim'. If pesher is taken to be 'the hidden mystery in a text clarified by its fulfillment' and midrash as

55 Cf. F. F. Bruce: ' $\ldots$ the divine promises made to David regarding his son and heir were not exhausted in Solomon' (The Epistle to the Hebrews [NICNT; Grand Rapids: Eerdmans, 1985], 14).

56 Contra R. McL. Wilson, Hebrews. (NCB Commentary; Grand Rapids: Eerdmans, 1987), 37.

57 The introductory formulae might, however, also be taken as commentary by the author - especially within the catena of Hebrews 1.

58 See E. Tönges for a list of passages that were identified by scholars as midrashim in Hebrews ('JesusMidrash', in G. Gelardini (ed), Hebrews: Contemporary Methods - New Insights. [Leiden: Brill, 2005], 107-27, here 91-2.). 
'a combining of Scriptures so as to give a new interpretation with an application to new situations according to personal experience or some event, ${ }^{59}$ then the commentaries on the quotations in Hebrews are probably closer to being midrash than pesher.

\section{d. The process}

This process might be understood within the typical stages of tradition development within the historical critical paradigm. Thus, given all our information, one might attempt to reconstruct the process as follows:

\section{Stage I: The text critical reconstruction - A written Vorlage}

It can be assumed that the version (text, or text reading) of the quotations in Hebrews ultimately represents a written Vorlage. This can be observed in light of the fact that those readings are closer to the Greek version(s) of the Old Testament. This Vorlage differs at some points from the reconstructed eclectic LXX editions today, but traces of these 'differences' were found in textual witnesses. The suspicion of scholars that another Textvorlage underlies the 'differences' of the quotations is thus justified although it needs to be qualified in each particular case. The text critical analysis of this investigation attempted to investigate this stage and it was established that Hebrews' background and theology shows similarities to those of Philo's Therapeutae and with that of the Qumran community. The author of Hebrews might be himself a converted Hellenistic Jew.

\section{Stage II: The form critical stage - Formulas and liturgies}

Some of these written texts were used by early Judaism and early Christianity specifically in the oral stages through formulas and liturgies. They became known in temple, synagogue and early church rituals, festivals, prayers and services. Evidence of this in Hebrews is seen in the high frequency of Psalm quotations, hymnic tendencies, the cultic nature of the book and connections with feasts - such as the climactic ending of the book with Ps 118(117). Thus, there also seem to be some truth in the liturgy hypothesis. The author of Hebrews draws on cultic rituals and liturgies with close connections to the Jewish festival calendar and its important feasts (especially to the pilgrimage festivals).

\section{Stage III: Literary critical stage - A 'promise' collection}

Contrary to the 'Testimony Book' hypothesis, no convincing evidence has been found about the existence of an early Christian testimony book or collection. If this had been the case, then one would have expected not only statistical evidence of more (of the same) quotation combinations in the literature, but also more specific, combinations of the

59 E. Ferguson, Backgrounds of Early Christianity (Grand Rapids: Eerdmans, 1993), 509. 
same quotations in other related and pre-Hebrews literature. What is striking, however, is the fact that the quotations in Hebrews are closely connected to 'promises'. The author most probably compiled his own 'testimonia collection' based on particular themes. This has been structured into two sets of seven pairs of quotations, which ultimately formed the ground plan or structure of Hebrews (and also of this investigation). The author's selection of passages came to a large extent from the existing early Jewish and early Christian citation traditions, although he added some longer passages that he selected himself. These are compiled into a selection of 'promise'-traditions which were probably developed against the backdrop of the festivals.

\section{Stage IV: Redaction criticism - Midrashic exposition}

During the compositional and redactional stages of his book, the author of Hebrews adapted and interpreted his quotations by making some stylistic and theological alterations to the text of the quotation itself. There are few changes and those that do occur are minute changes, mainly consisting of substitutions and transpositions. Instead of substantially altering the text of his quotation, the author rather adds his own exegetical commentary in the form of early Christian midrashim which display hymnic tendencies and paraphrasing, often using the gezerah shewah technique, as part of his rhetorical exposition. There is thus some truth in the midrash hypothesis as well - but not in the sense that the book has been molded on the basis of a midrash on Ps 110 . The homily hypothesis, however, seems to be too hypothetical to be taken seriously into consideration.

In order to establish the origin and versions used for the quotations in Hebrews, the route that was chosen took us back and forth through these stages. The only starting point before one can even attempt to venture into discussions on the author's application of his Scriptures, or the function of the quotations within their new context, should thus be the quest for the Vorlage of these quotations. ${ }^{60}$

\section{CONCLUSION}

Writing is the 'packaging' of concepts and ideas in written language. It is the fossilization, sediment and deposit of concepts initially transmitted by oral traditions but most often only represents just one form, a single snapshot, in a series of tradition mutations. A written document represents the stagnated version of oral concepts and ideas at a given point in time. Investigations on the explicit quotations in Ad Hebraeos confirm the fusion of oral and literal traditions when using authoritative 'Scripture' during the process of its compilation. By relying largely on the Jewish hermeneutical approach of gezerah shewah, the author draws, on the one hand, from the orality pool of hymnic material familiar to him - not only from festivals, rituals and liturgies, but also from the pool of living 'promises.' On the other hand, however, the author draws from

60 G. J. Steyn, A Quest for the Assumed LXX Vorlage, 403-408. 
the pool of known quotations in circulation amongst early Jewish and early Christian communities and as reflected in the literature of these groups. Quotations that were used by Philo, Paul and the gospel writers surface again in Hebrews - sometimes in the same format, sometimes in expanded form. But it is especially this expansion by the author on the known pre-Hebrews quotations, as well as his own addition of several other (long) quotations, which reflects the author's own first-hand familiarity with, personal study and exposition of his Scriptures - a practice which finds parallels amongst Philo's Therapeutae.

It is not difficult to depict the author of Hebrews as a highly educated man, not only in the Jewish religious traditions, but also in Greek philosophy and rhetoric- most probably as a Hellenistic Jew in lower Egypt - who studied the Scriptures (perhaps even utilizing the famous library of Alexandria?), participated in Jewish festivals and early Christian rituals, being familiar with a repertoire of promise-traditions from Jewish oral history, and compiling his 'speech of exhortation' from this pool of resource material. The author lives in both an oral and a written world and draws from both during the compilation of his document. Hebrews represents a document at an advanced stage in the history of first century early Christianity and fuses oral and written traditions. But this is not just a random design. This is a well-planned and well-thought through document.

\section{BIBLIOGRAPHY}

Arnold, Bill T. and Hugh G.M. Williamson, Dictionary of the Old Testament: Historical Books. Downers Grove: InterVarsity Press, 2005.

Barth, Markus. 'The Old Testament in Hebrews: An Essay in Biblical Hermeneutics.' Pages 53-78 in Current Issues in New Testament Interpretation. Essays in honor of Otto A. Piper. Edited by William Klassen \& Graydon F. Snyder. London: SCM Press, 1962.

Botha, Pieter J.J. Orality and Literacy in Early Christianity. Eugene: Cascade Books, 2012.

Bruce, Frederick F. The Epistle to the Hebrews (NICNT). Grand Rapids: Eerdmans, 1985.

Burkhardt, Hans. Die Inspiration heiliger Schriften bei Philo von Alexandrien. Basel: Brunnen, 1988.

DeSilva, David A. Introducing the Apocrypha: Message, Context, and Significance. Grand Rapids: Baker Academic, 2002.

Ferguson, Everett. Backgrounds of Early Christianity. Grand Rapids: Eerdmans, 1993.

Gerhardsson, Birger. Memory and Manuscript: Oral Tradition and Written Transmission in Rabbinic Judaism and Early Christianity. ASNU XXII. Lund: Gleerup, 1961.

Guthrie, George H. The Structure of Hebrews: A text-linguistic analysis. NT.S 73. Leiden: Brill, 1994.

Kistemaker, Simon J. New Testament Commentary. Exposition of the Epistle to the Hebrews. Grand Rapids: Baker Book House, 1984.

Kitchen, Kenneth A. 'Egyptian.' Page 863 in New Bible Dictionary. Edited by Derek R.W. Wood. Downers Grove: InterVarsity Press, 1996.

Kravitz, Nathaniel. 3,000 years of Hebrew Literature from the earliest time through the $20^{\text {th }}$ century. Chicago: The Swallow Press, 1972. 
Lindenberger, James M. 'Letters.' Page 883 in The Eerdmans Dictionary of Early Judaism. Edited by John J. Collins and Daniel C. Harlow. Grand Rapids: Eerdmans, 2010.

Mason, Steven N. 'Jewish Theologies and Sects.' In Dictionary of New Testament Background. Edited by Craig A. Evans and Stanley E. Porter. Downers Grove: electronic edition, 2000.

Metzger, Bruce M. Manuscripts of the Greek Bible: An Introduction to Greek Palaeography. Oxford: University Press, 1981.

Moody Smith, Dwight. 'The Use of the Old Testament in the New.' Pages 3-65 in The Use of the Old Testament in the New and Other Essays: Studies in honor of William Franklin Stinespring. Edited by James M. Efird. Durham: Duke University Press, 1972.

Steyn, Gert J. 'Reflections on the Reception of the LXX Pentateuch in Philo's De Vita Mosis.' Pages 363-380 in Die Septuaginta: Text, Wirkung, Rezeption. 4. Internationale Fachtagung veranstaltet von Septuaginta Deutsch (LXX.D), Wuppertal 19.-22. Juli 2012. Edited by Wolfgang Kraus and Siegfried Kreuzer. WUNT I 325. Tübingen: Mohr Siebeck, 2014.

Steyn, Gert J. A Quest for the Assumed LXX Vorlage of the Explicit Quotations in Hebrews. FRLANT 235. Göttingen: Vandenhoeck \& Ruprecht, 2011.

Steyn, Gert J. 'The Eschatology of Hebews as understood within a cultic setting.' Pages 429-450 in Eschatology of the New Testament and Some Related Documents. Edited by Jan G. van der Watt. WUNT 315. Tübingen: Mohr Siebeck, 2011.

Steyn, Gert J. “"Perfecting Knowledge and Piety” (Philo, Contempl. 3,25). Similarities between Philo’s Therapeutae and Lukan Early Christianity.' Neotestamentica 43.2 (2009): 178-202.

Steyn, Gert J. 'An overview of the extent and diversity of methods utilised by the author of Hebrews when using the Old Testament.' Neotestamentica 42.2 (2008): 327-352.

Steyn, Gert J. 'Psalm 2 in Hebrews.’ Neotestamentica 37.2 (2003): 262-282.

Steyn, Gert J. 'Addressing an angelomorphic christological myth in Hebrews?' HTS Theological Studies 59.4 (2003): 1107-1128.

Steyn, Gert J. 'The Vorlage of the Melchizedek phrases in Heb 7:1-4.' Acta Patristica et Byzantina 13 (2002): 207-223.

Steyn, Gert J. 'Luke's use of Mimesis? Re-opening the debate.' Pages 551-558 in The Scriptures in the Gospels. (Congress Volume of Papers delivered at the Colloquium Biblicum Lovaniense 51st Congress, August 1996). Edited by Christopher M. Tuckett. BETL 131. Leuven: Peeters Press, 1997.

Steyn, Gert J. Septuagint Quotations in the Context of the Petrine and Pauline Speeches of the Acta Apostolorum. Kampen: Kok Pharos, 1995.

Tönges, Elke. 'Jesus-Midrash.' Pages 107-127 in Hebrews: Contemporary Methods - New Insights. Edited by Gabriela Gelardini. Leiden: Brill, 2005.

Van den Brink, Gijsbert. 'De schrift zegt of de Schrift fantaseert? Het gebruik van het Oude Testament in Hebreeën.' Pages 211-217 in Verkenningen in de katholieke brieven en Hebreeën. Edited by Gijsbert van den Brink. Kampen: Kok Voorhoeve, 1993.

Wilson, R. McLellan. Hebrews. NCB Commentary. Grand Rapids: Eerdmans, 1987.

Winter, Bruce W. Philo and Paul amongst the Sophists. Cambridge: Cambridge University Press, 1997. 